EFFICIENT

\title{
Analisis Kinerja Keuangan dan Ekonomi Pemerintah Daerah Sebelum dan Setelah Pemekaran (Studi Kasus Pemekaran di Papua)
}

\author{
Muhamad Nur Salim \\ Jurusan Ekonomi Pembangunan, Fakultas Ekonomi, Universitas Negeri Semarang \\ Permalink/DOI: https://doi.org/10.15294/efficient.v2i2.29162
}

Received: December 2018 ; Accepted: March 2019; Published: Juny 2019

\begin{abstract}
The expansion in 2008 generate 30 new autonomous region of 21 parent area. Papua is a region with the second largest carrier regions undergoing expansion in 2008 that is as much as four regional carriers. Four areas of the stem has abundant natural resources, which if managed with optimal will make an impact on donations of original income areas to areas in Papua region. But in point of fact many areas in Papua which is undergoing expansion in 2008 has a low degree of fiscal decentralization before and after undergoing expansion. This indicated a still low level of contributions to the total income of the PAD area. The purpose of this research was to analyze financial performance differences in the degree of fiscal decentralization aspect and the financial independence of the region as well as the performance of the economy in the aspect of the growth of GDP per capita and the degree of poverty before and after undergoing expansion. The sample in this study consists of four district/parent area in Papua. This research method using statistical analysis descriptive quantitative analysis techniques with test paired sample t-test. The result there is a significant difference to the level of poverty in all districts, there is a significance to the growth of GDP per capita in the Regency of Puncak Jaya, and there was no significant difference in financial performance, namely the degree of fiscal decentralization and financial independence of the area before and after the expansion.
\end{abstract}

Keywords: Finance Performance; Economic Performance; Local Government; and Expansion.

\begin{abstract}
Abstrak
Pemekaran pada tahun 2008 menghasilkan 30 daerah otonomi baru dari 21 daerah induk. Papua adalah wilayah dengan daerah induk terbanyak kedua yang mengalami pemekaran pada tahun 2008 yaitu sebanyak empat daerah induk. Ke-empat daerah induk tersebut mempunyai sumber daya alam yang melimpah, yang apabila dikelola dengan optimal akan memberi dampak pada sumbangan pendapatan asli daerah bagi daerah di wilayah Papua. Namun pada nyatanya banyak daerah di Papua yang mengalami pemekaran tahun 2008 memiliki nilai derajat desentralisasi fiskal yang rendah sebelum dan setelah mengalami pemekaran. Hal ini mengindikasikan masih rendahnya kontribusi PAD terhadap total pendapatan daerah. Tujuan penelitian ini untuk menganalisis perbedaan kinerja keuangan dalam aspek derajat desentralisasi fiskal dan kemandirian keuangan daerah serta kinerja ekonomi dalam aspek pertumbuhan PDRB per kapita dan tingkat kemiskinan sebelum dan setelah mengalami pemekaran. Sampel dalam penelitian ini terdiri dari empat kabupaten/ daerah induk di Papua. Metode penelitian ini menggunakan analisis statistik deskriptif kuantitatif dengan teknik analisis uji paired sample t-test. Hasilnya terdapat perbedaan yang signifikan untuk tingkat kemiskinan di semua kabupaten, terdapat signifikansi pada pertumbuhan PDRB per kapita di Kabupaten Puncak Jaya, dan tidak terdapat perbedaan yang signifikan pada kinerja keuangan yaitu derajat desentralisasi fiskal dan kemandirian keuangan daerah sebelum dan setelah mengalami pemekaran.
\end{abstract}

Kata Kunci: Kinerja Keuangan; Kinerja Ekonomi; Pemerintah Daerah; dan Pemekaran.

How to Cite: Salim, M. (2019). Analisis Kinerja Keuangan dan Ekonomi Pemerintah Daerah Sebelum dan Setelah Pemekaran. Efficient: Indonesian Journal of Development Economics, 2(2), 436-451. https://doi.org/10.15294/efficient.v2i2.29162

(C) 2019 Semarang State University. All rights reserved

\footnotetext{
Alamat Korespondensi :

Alamat: Gedung L2 Lantai 2 FE Unnes

Kampus Sekaran, Gunungpati, Semarang, 50229

E-mail : efficientjournal@gmail.com
}

ISSN 2655-6197 


\section{PENDAHULUAN}

Pemekaran wilayah di Indonesia yang didengungkan sejak paska reformasi sepuluh tahun lebih silam ternyata masih jauh dari harapan masyarakat untuk membawa perekonomian daerah dan kesejahteraan rakyat menjadi lebih baik. Rentang waktu 15 tahun proses pemekaran daerah, terus berlangsung hampir setiap tahun dan menghasilkan 175 daerah otonom baru, berikut data pemekaran daerah dari tahun 2001-2014 disajikan dalam tabel

Tabel 1. Pemekaran Daerah di Indonesia Periode 2001-2014

\begin{tabular}{|c|c|c|c|c|c|}
\hline Tahun & Bulan & Jml Provinsi Baru & Jml Kabupaten Baru & Jml Kota Baru & Total \\
\hline 2001 & Juni & - & - & 12 & 12 \\
\hline \multirow[t]{3}{*}{2002} & April & 1 & 18 & 3 & 22 \\
\hline & Oktober & 1 & 9 & 1 & 11 \\
\hline & Desember & - & 5 & - & 5 \\
\hline \multirow[t]{2}{*}{2003} & Februari & - & 23 & 2 & 25 \\
\hline & Desember & - & 24 & - & 24 \\
\hline \multirow[t]{3}{*}{2007} & Januari & - & 15 & 2 & 17 \\
\hline & Maret & - & 1 & - & 1 \\
\hline & Agustus & - & 6 & 2 & 8 \\
\hline \multirow[t]{3}{*}{2008} & Januari & - & 6 & - & 6 \\
\hline & Juli & - & 10 & 1 & 11 \\
\hline & November & - & 11 & 2 & 13 \\
\hline 2009 & Januari & - & 2 & - & 2 \\
\hline \multirow[t]{2}{*}{2012} & Oktober & 1 & - & - & 1 \\
\hline & November & - & 4 & - & 4 \\
\hline \multirow[t]{3}{*}{2013} & Januari & - & 7 & - & 7 \\
\hline & Mei & - & 2 & - & 2 \\
\hline & Juli & - & 1 & - & 1 \\
\hline \multirow[t]{2}{*}{2014} & Juli & - & 3 & - & 3 \\
\hline & Jumlah & 3 & 147 & 25 & 175 \\
\hline
\end{tabular}

Sumber : Dirjen Otoda, Kemendagri 2014, data diolah

Berdasarkan data di atas, pemekaran dengan jumlah daerah terbanyak adalah pada tahun 2003 sebanyak 49 daerah otonom baru (DOB), dengan rata 12,5 DOB per tahun. Secara umum pada tahun 2008 dimana tahun tengah dari 2001-2014, jika dilihat dari tabel diatas ada sekitar 30 pemekaran atau daerah otonom baru kabupaten dan kota. Daerah tersebut ditampilkan dalam tabel 2.

Berdasarkan tabel di atas, wilayah Papua adalah wilayah terbanyak kedua yang melakukan pemekaran yaitu sebanyak empat daerah induk. Papua adalah wilayah yang mempunyai sumber daya alam yang 
melimpah, yang apabila dikelola dengan baik tersebut adalah Kabupaten Jayawijaya, akan meningkatkan pendapatan bagi daerah Kabupaten Puncak Jaya, Kabupaten Nabire, yang ada di wilayah Papua. Ke-empat daerah dan Kabupaten Paniai.

Tabel 2. Daerah Induk dan Daerah Otonom Baru Hasil Pemekaran Tahun 2008

\begin{tabular}{|c|c|c|}
\hline No & Daerah Induk & Daerah Otonom Baru \\
\hline \multirow[t]{2}{*}{1} & Kab. Labuhanbatu (SUMUT) & Kab. Labuhanbatu Selatan \\
\hline & & Kab. Labihanbatu Utara \\
\hline \multirow[t]{3}{*}{2} & Kab. Nias (SUMUT) & Kab. Nias Utara \\
\hline & & Kab. Nias Barat \\
\hline & & Kota Gunungsitoli \\
\hline 3 & Kab. Kerinci (Jambi) & Kota Sungai Penuh \\
\hline 4 & Kab. Natuna (Kep. Riau) & Kab. Kepulauan Anambas \\
\hline 5 & Kab. Bengkulu Utara (Bengkulu) & Kab. Bengkulu Tengah \\
\hline 6 & Kab. Tanggamus (Lampung) & Kab. Pringsewu \\
\hline \multirow[t]{2}{*}{7} & Kab. Tulangbawang (Lampung) & Kab. Tulangbawang Barat \\
\hline & & Kab. Mesuji \\
\hline 8 & Kab. Tangerang (Banten) & Kota Tangerang Selatan \\
\hline 9 & Kab. Lombok Barat (NTB) & Kab. Lombok Utara \\
\hline 10 & Kab. Kupang (NTT) & Kab. Sabu Raijau \\
\hline 11 & Kab. Donggala (SULTENG) & Kabupaten Sigi \\
\hline \multirow[t]{2}{*}{12} & Kab. Bolaang Mongondow (SULUT) & Kab. Bolang Mongondow Timur \\
\hline & & Kab. Bolaang Mongondow Selatan \\
\hline 13 & Kab. Tana Toraja (SULSEL) & Kab. Toraja Utara \\
\hline 14 & Kab. Maluku Tenggara Barat (Maluku) & Kab. Maluku Barat Daya \\
\hline 15 & Kab. Kepulauan Buru (MALUT) & Kab. Buru Selatan \\
\hline 16 & Kab. Halmahera Utara (MALUT) & Kab. Pulau Morotai \\
\hline \multirow[t]{4}{*}{17} & Kab. Jayawijaya (Papua) & Kab. Mambremo Tengah \\
\hline & & Kab. Yalimo \\
\hline & & Kab. Lanny Jaya \\
\hline & & Kab. Nduga \\
\hline 18 & Kab. Puncak Jaya (Papua) & Kab. Puncak \\
\hline 19 & Kab. Nabire (Papua) & Kab. Dogiyai \\
\hline \multirow[t]{2}{*}{20} & Kab. Paniai (Papua) & Kab. Intan Jaya \\
\hline & & Kab. Deiyai \\
\hline 21 & $\begin{array}{l}\text { Kab. Sorong \& Kab. Manokwari (Papua } \\
\text { Barat) }\end{array}$ & Kab. Tambrauw \\
\hline
\end{tabular}

Sumber : Dirjen Otoda, Kemendagri 2014, data diolah. 
Tujuan adanya pemekaran adalah untuk mempersingkat rentang kendali antara pemerintah dan masyarakat, khususnya pada wilayah-wilayah yang belum terjangkau oleh fasilitas pemerintahan (PP/78 2008 Pasal 6). Melalui hal tersebut, pemerintah daerah di upayakan dapat menggali potensi pendapatan daerah. Sehingga rasio derajat desentralisasi fiskal (DDF) dapat meningkat setelah pemekaran. Namun pada nyatanya, banyak daerah di Papua yang mengalami pemekaran pada tahun 2008 belum sesuai dengan tujuan. Berikut adalah nilai DDF pada tahun 2007, 2010, dan 2014 akan disajikan pada gambar 1.

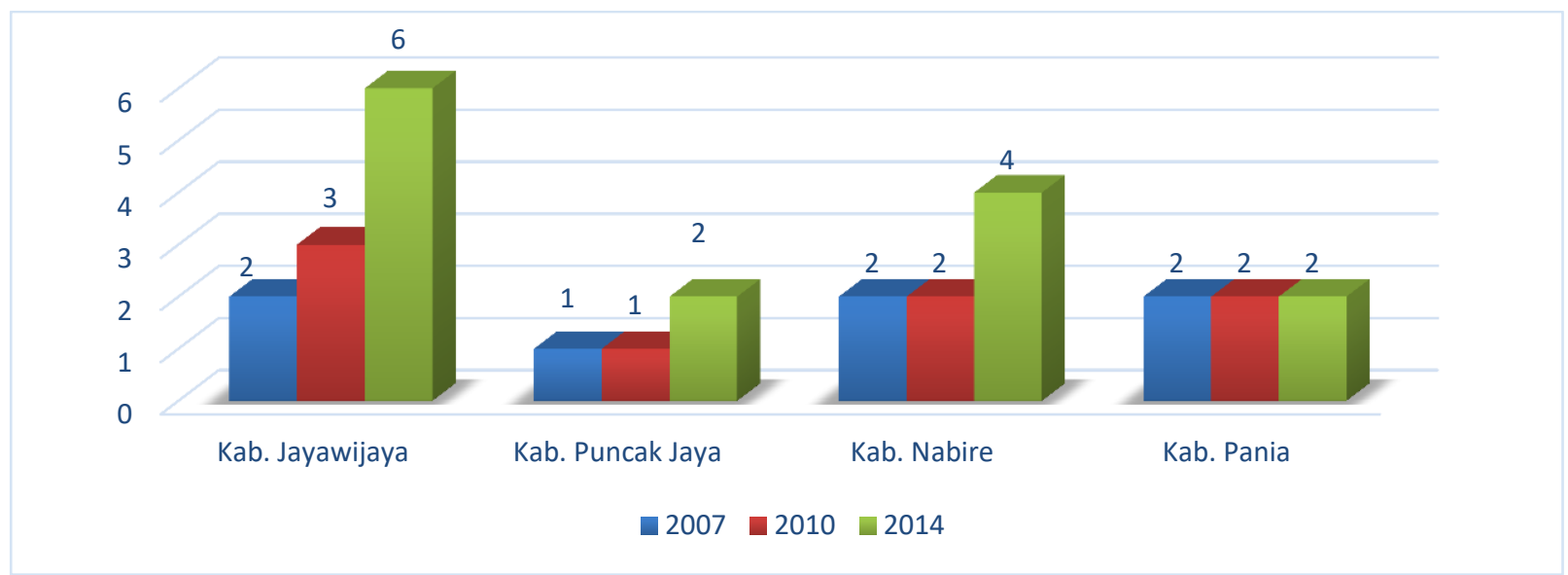

Gambar 1. Derajat Desentralisasi Fiskal Daerah di Papua Pemekaran 2008 Tahun 2007, 2010, dan 2014

Sumber : Data diolah dari APBD se Indonesia.

Kontribusi pendapatan asli daerah terhadap total pendapatan daerah menjadi salah satu indikator kinerja keuangan daerah, baik daerah induk yang mengalami pemekaran maupun daerah hasil pemekaran. Pada tahun 2007 atau satu tahun sebelum kabupatenkabupaten di Papua mengalami pemekaran, nilai DDF untuk semua kabupaten cenderung dibawah 10 persen yang berarti kemampuan keuangan daerahnya masih dalam kategori sangat kurang. Setelah mengalami pemekaran, pada tahun 2010 tidak terjadi kenaikan kecuali pada Kabupaten Jayawijaya yang mengalami pertumbuhan walau kecil dengan rata-rata 1-2 persen. Pada tahun 2014 terjadi kenaikan antara 1-3 persen, kecuali Kabupaten Paniai yang tetap atau tidak mengalami kenaikan maupun penurunan. Pemekaran berpengaruh positif terhadap nilai DDF di Kabupaten Jayawijaya, Kabupaten Puncak Jaya, dan Kabupaten Nabire (skala menggunakan skala interval Tim Fisipol UGM).

Menurut Suseno (2013) dalam implementasinya dekonsentrasi merupakan sarana bagi perangkat birokrasi pusat untuk menjalankan praktek sentralisasi yang terselubung sehingga kemandirian daerah menjadi terhambat. Hal ini menujukan peran pemerintah pusat masih dominan dalam hal kinerja keuangan di daerah.

Menurut Olawade (2011) di dalam Yunus Gunawan (2013) bahwa sumber pendapatan utama yang seringkali menjadi parameter untuk menentukan derajat otonomi fiskal yang 
dimiliki oleh suatu daerah adalah pendapatan yang diperoleh pemerintah daerah yaitu pendapatan yang diterima yang berasal dari sumber-sumber yang dikelola oleh pemerintah daerah itu sendiri (local source).

Kemiskinan juga menjadi indikator kesejahteraan masyarakat yang tertuang dalam tujuan pemekaran, untuk meningkatkan kesejahteraan masyarakat ( $\left.\mathrm{PP}_{7} 8 / 2007\right)$. Berikut data tingkat kemiskinan di kabupatenkabupaten di Papua sebelum dan setelah mengalami pemekaran pada tahun 2008, selanjutnya disajikan dalam gambar 2.

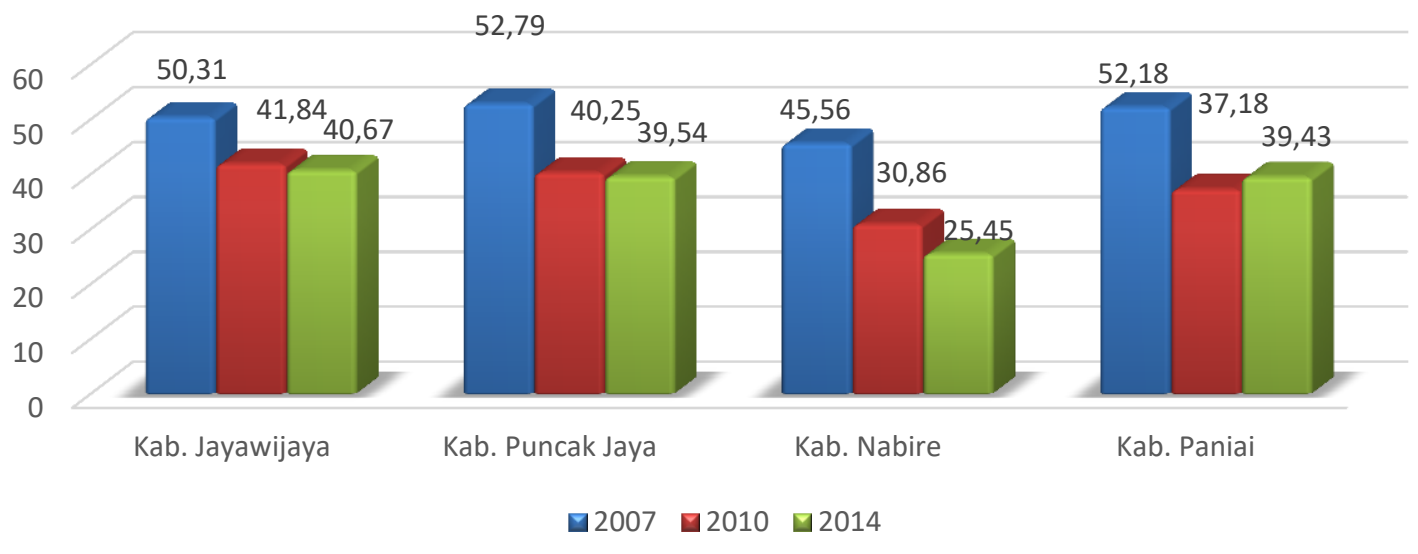

Gambar 2. Tingkat Kemiskinan Daerah Di Papua Pemekaran 2008 Tahun 2007, 2010, dan 2014 Sumber : Daerah Dalam Angka Papua, BPS.

Berdasarkan gambar 2 dapat dilihat bahwa adanya pemekaran telah memberikan efek besar terhadap penurunan tingkat kemiskinan di semua kabupaten di Papua, adanya pemekaran berpengaruh terhadap penurunan tingkat kemiskinan dari tingkat tertinggi di Kabupaten Puncak Jaya pada tahun 2007 yaitu sebesar $\mathbf{5 2 . 7 9}$ persen, dan Kabupaten Paniai sebesar 52.18 persen. Setelah mengalami pemekaran yaitu tahun 2010, semua kabupaten mengalami penurunan kemiskinan dengan penurunan tertinggi oleh Kabupaten Paniai sebesar 15.00 persen, dan Kabupaten Nabire sebesar 14.70 persen. Menurut Rusli Abdullah (2013), program penanggulangan kemiskinan sebenarnya terus dilaksanakan pemerintah mulai dari inpres desa tertinggal (IDT), program kompensasi pengalihan subsidi BBM dan lain sebagainya. Namun program tersebut bersifat jangka pendek dan tidak memberikan pelatihan keterampilan yang berkelanjutan.

Windhu Putra (2012) melihat pola pemekaran yaitu prinsip pemekaran daerah di Indonesia sebagai negara kepulauan daerah tropis memiliki karakteristik tersendiri, selain ditinjau dari besarnya jumlah penduduk yang tersebar tidak merata juga dilihat dari keanekaragaman sosial budaya, sumber daya alam, flora dan fauna serta keragaman fisik wilayah. Jika dilihat sejarahnya, konsep mengenai pemekaran wilayah itu sendiri sebenarnya pertama kali dikemukakan oleh Tiebout (1956) dalam sebuah artikel yang berjudul "A Pure Theory of Local Expenditure". Dinyatakan bahwa pemekaran wilayah 
dianalogikan sebagai model ekonomi persaingan sempurna dimana pemerintahan daerah memiliki kekuatan untuk mempertahankan tingkat pajak yang rendah, menyediakan pelayanan yang efisien, dan mengizinkan setiap individu masyarakatnya untuk mengekspresikan preferensi nya untuk setiap jenis pelayanan dari berbagai tingkat pemerintahan yang berbeda dengan "vote with their feet".

Endang Sri Mulatsih (2014) dalam penelitian Analisis Kemampuan Keuangan Daerah Kabupaten/Kota Di Provinsi Sumatera Selatan Sebelum dan Setelah Pemekaran Daerah menemukan pemekaran daerah tidak berpengaruh terhadap rasio desentralisasi fiskal. Allana Talita Zabrina (2013) dalam penelitian Analisis Kinerja Keuangan Pemerintah Daerah Sebelum dan Sesudah Pemekaran menemukan tidak adanya perbedaan rasio kemandirian keuangan daerah dan rasio-rasio lainnya.

Ida Ayu P.R (2012) dalam penelitian "Analisis Dampak Pemekaran Wilayah Terhadap Pendapatan Per Kapita, Kemiskinan, dan Ketimpangan Antar Wilayah di Provinsi Papua“, menemukan secara keseluruhan pemekaran wilayah mempunyai pengaruh yang signifikan terhadap penurunan tingkat kemiskinan di Provinsi Papua.

Tujuan dari penelitian ini untuk melihat dan mengetahui apakah ada atau tidaknya pemekaran terhadap derajat desentralisasi fiskal, kemandirian keuangan, pertumbuhan PDRB per kapita, dan kemiskinan melalui analisis kinerja keuangan dan kinerja ekonomi pemerintah daerah sebelum dan setelah pemekaran.

\section{METODE PENELITIAN}

Penelitian ini digolongkan pada penelitian deskriptif kuantitatif dengan tujuan untuk mendeskripsikan atau menjelaskan sesuatu hal seperti apa adanya. Sampel penelitian ini adalah enam kabupaten di wilayah Sumatera yang mengalami pemekaran pada tahun 2008. Data yang digunakan adalah data yang berbentuk angka, tentang realisasi anggaran pendapatan dan belanja daerah (APBD) pemerintah Kabupaten /Kota menjadi dasar perhitungan kinerja keuangan untuk periode sebelum dan setelah pemekaran daerah pada daerah induk yang mengalami pemekaran. Data Pertumbuhan PDRB Atas Dasar Harga Konstan dan tingkat kemiskinan sebelum dan setelah pemekaran menjadi dasar perhitungan kinerja ekonomi daerah, dengan rentang tiga tahun sebelum pemekaran (2006-2008) dan tiga tahun terakhir (2012-2014). Data yang digunakan dalam penelitian ini dikumpulkan dengan metode dokumentasi, dengan mengumpulkan dan mempelajari dokumen-dokumen dan data-data yang diperlukan. Data yang digunakan dalam penelitian ini adalah data sekunder dari laporan realisasi APBD yang berasal dari dokumen-dokumen akuntansi dan operasi yang dikumpulkan oleh Kementerian Keuangan melalui Dirjen Perimbangan Keuangan, BAPPENAS, dan Badan Pusat Statistik menggunakan data keuangan dan ekonomi tahunan selama tahun 2006-2014. 


\section{Analisis Statistik Deskriptif}

Analisis statistik deskriptif yaitu dengan menghitung kinerja keuangan masing-masing daerah induk pemekaran berdasarkan rasiorasio yang dipergunakan.

\section{Analisis Uji Dua Sampel Berpasangan}

Analisis uji dua sampel berpasangan yaitu dengan membandingkan hasil masing- masing rasio secara rata-rata untuk seluruh daerah induk pemekaran.

\section{HASIL DAN PEMBAHASAN}

\section{Kabupaten Jayawijaya}

Berikut tabel hasil perhitungan rasio rata-rata per periode Kabupaten Jayawijaya.

Tabel 3. Hasil Perhitungan Rasio Rata-rata Per Periode Kab. Jayawijaya

\begin{tabular}{llll}
\hline Jenis Kinerja & Rumus Rasio & Sebelum & Setelah \\
\hline Derajat Desentralisasi Fiskal & PAD/TPD X 100 & 2.33 & 4.00 \\
Kemandirian Keu Daerah & PAD/DPD X 100 & 2.33 & 4.33 \\
Pertumbuhan PDRB Per Kapita & PDRBt - PDRBt-1/PDRBt-1 & 7.83 & 12.47 \\
Tingkat Kemiskinan & $1 \frac{1}{n} \sum_{i-1}^{\alpha}\left[\left(\begin{array}{c}z-y i \\
z\end{array}\right)\right] \alpha$ & 49.70 & 40.51 \\
\hline
\end{tabular}

Pemekaran di Kabupaten Jayawijaya berpengaruh pada naiknya rata-rata nilai derajat desentralisasi fiskal (DDF). Sebelum pemekaran rata-rata nilai DDF Kabupaten Jayawijaya sebesar 2,33 persen naik menjadi 4,oo persen setelah pemekaran. Pemekaran juga berpengaruh pada naiknya nilai kemandirian keuangan daerah (KKD). Sebelum pemekaran rata-rata nilai KKD sebesar 2,33 persen dan naik menjadi 4,33. Pertumbuhan PDRB per kapita Kabupaten Jayawijaya sebelum pemekaran sebesar 7,83 persen naik menjadi 12,47 persen. Tingkat kemiskinan Kabupaten Jayawijaya turun dari 49,70 persen menjadi 40,51 persen. Berikut hasil uji statistik (Paired Sample T-Test) Kabupaten Jayawijaya.

Tabel 4. Hasil Uji Paired Sample T-Test Kab. Jayawijaya Sebelum dan Setelah Pemekaran

\begin{tabular}{|c|c|c|c|c|c|c|c|c|}
\hline \multicolumn{2}{|c|}{ Keterangan } & \multicolumn{7}{|c|}{ Paired Differences } \\
\hline & & \multirow[t]{4}{*}{ Mean } & \multirow[t]{4}{*}{ Std. Dev } & $95 \%$ & Confidence & \multirow{4}{*}{$\begin{array}{l}\mathrm{t} \\
\text { value }\end{array}$} & \multirow{4}{*}{$\begin{array}{l}D \\
f\end{array}$} & \multirow{4}{*}{$\begin{array}{l}\text { Sign. } \\
\text { tailed) }\end{array}$} \\
\hline & & & & Interval & the & & & \\
\hline & & & & \multicolumn{2}{|c|}{ Difference } & & & \\
\hline & & & & Lower & Upper & & & \\
\hline Pair 1 & DFA-DFB & 1.66667 & 1.15470 & -4.53510 & 1.20177 & -2.500 & 2 & .130 \\
\hline Pair 2 & KDA-KDB & -2.00000 & 1.00000 & -4.48414 & .48414 & -3.464 & 2 & .074 \\
\hline Pair 3 & PDA-PDB & -4.64667 & 2.29051 & -10.33661 & 1.04327 & -3.514 & 2 & .072 \\
\hline Pair 4 & TKA-TKB & 9.19333 & 2.14572 & 3.86306 & 14.52361 & $7 \cdot 421$ & 2 & .018 \\
\hline
\end{tabular}

Sumber : hasil uji paired sample t-test, SPSS 
Hasilnya, pemekaran berpengaruh memberikan dampak nyata terhadap naiknya signifikan terhadap tingkat kemiskinan, dan kemampuan keuangan daerah dan tidak berpengaruh signifikan terhadap DDF, pertumbuhan PDRB per kapita di Kabupaten KDA dan pertumbuhan PDRB per kapita. Hal Jayawijaya, di sisi lain berdampak pada ini berarti adanya pemekaran tidak turunnya tingkat kemiskinan.

\section{Kabupaten Puncak Jaya}

Berikut tabel hasil perhitungan rasio rata-rata per periode Kabupaten Puncak Jaya.

Tabel 5. Hasil Perhitungan Rasio Rata-rata Per Periode Kabupaten Puncak Jaya

\begin{tabular}{llll}
\hline Jenis Kinerja & Rumus Rasio & Sebelum & Setelah \\
\hline Desentralisasi Fiskal & PAD/TPD X 100 & 1.33 & 1.33 \\
Kemandirian Keu Daerah & PAD/DPD X 100 & 1.67 & 1.33 \\
Pertumbuhan PDRB Per Kapita & PDRBt - PDRBt-1/PDRBt-1 & 19.80 & 4.21 \\
Tingkat Kemiskinan & $1 \frac{1}{n} \sum_{i-1}^{\alpha}\left[\left(\begin{array}{c}z-y i \\
z\end{array}\right)\right] \alpha$ & 52.14 & 39.22 \\
\hline
\end{tabular}

Pemekaran di Kabupaten Puncak Jaya berdampak pada penurunan semua aspek, yaitu turunnya atau tidak mengalami perbedaan pada rata-rata nilai derajat desentralisasi fiskal (DDF). Sebelum pemekaran rata-rata nilai DDF Kabupaten Puncak Jaya sebesar 1,33 persen dan tetap 1,33 persen setelah pemekaran. Pemekaran juga berpengaruh pada turunnya nilai kemandirian keuangan daerah (KKD). Sebelum pemekaran rata-rata nilai KKD sebesar 1,67 persen dan turun menjadi 1,33. Pertumbuhan PDRB per kapita Kabupaten Puncak Jaya sebelum pemekaran sebesar 19,80 persen turun tajam menjadi 4,21 persen. Sementara itu, tingkat kemiskinan Kabupaten Puncak Jaya turun dari 52,14 persen menjadi 39,22 persen. Berikut hasil uji statistik (Paired Sample T-Test) Kabupaten Puncak Jaya.

Tabel 6. Hasil Uji Paired Sample T-Test Kab. Puncak Jaya Sebelum dan Setelah Pemekaran

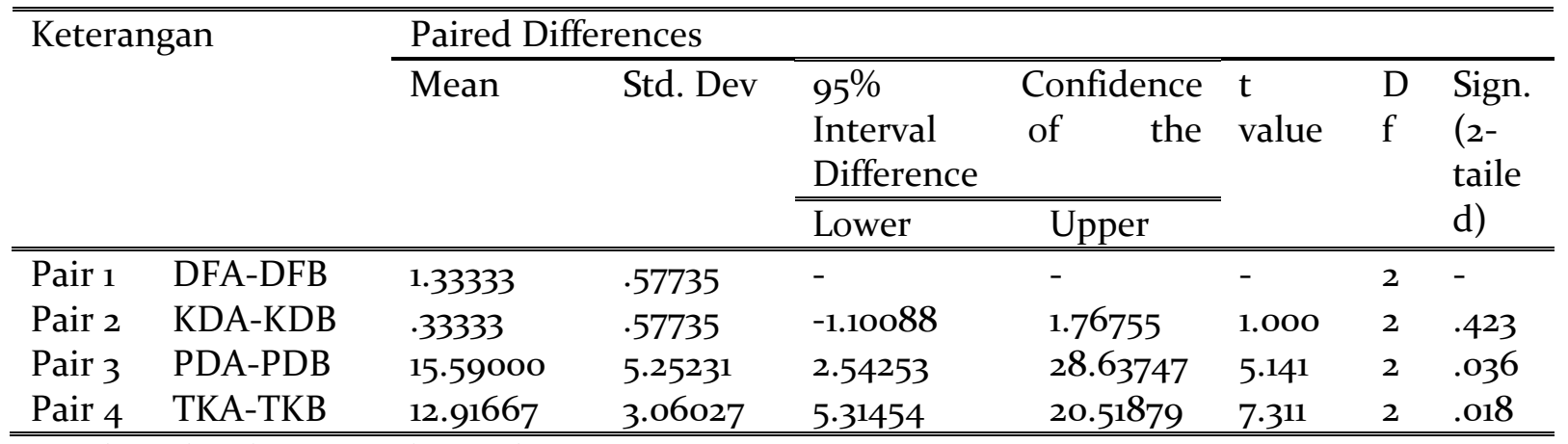

Sumber : hasil uji paired sample t-test, SPSS. 
Hasilnya, pemekaran berpengaruh signifikan terhadap tingkat kemiskinan dan pertumbuhan PDRB per kapita, dan tidak berpengaruh signifikan terhadap KKD, dan terhadap DDF memiliki variansi nol sehingga tidak dapat diuji. Hal ini berarti adanya pemekaran memberikan dampak nyata terhadap turunnya pertumbuhan PDRB per kapita dan tingkat kemiskinan di Kabupaten Puncak Jaya, di sisi lain tidak berdampak pada kemampuan keuangan daerah.

\section{KAB. NABIRE}

Berikut tabel hasil perhitungan rasio rata-rata per periode Kabupaten Nabire.

Pemekaran di Kabupaten Nabire berpengaruh pada naiknya rata-rata nilai derajat desentralisasi fiskal (DDF). Sebelum pemekaran rata-rata nilai DDF Kabupaten Nabire sebesar 2,00 persen naik menjadi 3,00 persen setelah pemekaran. Pemekaran juga berpengaruh pada naiknya nilai kemandirian keuangan daerah (KKD). Sebelum pemekaran rata-rata nilai KKD sebesar 2,00 persen dan naik menjadi 3,33. Pertumbuhan PDRB per kapita Kabupaten Nabire sebelum pemekaran sebesar 12,25 persen naik menjadi 15,09 persen. Tingkat kemiskinan Kabupaten Nabire turun dari 42,94 persen menjadi 27,93 persen. Berikut hasil uji statistik (Paired Sample TTest) Kabupaten Nabire.

Tabel 7. Hasil Perhitungan Rasio Rata-rata Per Periode Kabupaten Nabire

\begin{tabular}{llll}
\hline \hline Jenis Kinerja & Rumus Rasio & Sebelum & Setelah \\
\hline \hline Desentralisasi Fiskal & PAD/TPD X 100 & 2.00 & 3.00 \\
Kemandirian Keu Daerah & PAD/DPD X 100 & $\mathbf{2 . 0 0}$ & 3.33 \\
Pertumbuhan PDRB Per Kapita & PDRBt - PDRBt-1/PDRBt-1 & $\mathbf{1 2 . 2 5}$ & $\mathbf{1 5 . 0 9}$ \\
Tingkat Kemiskinan & $1 \frac{1}{n} \sum_{i-1}^{\alpha}\left[\left(\begin{array}{c}z-y i \\
z\end{array}\right)\right] \alpha$ & 42.94 & 27.93 \\
\hline \hline
\end{tabular}

Hasilnya, pemekaran tidak nyata terhadap kemampuan keuangan daerah, berpengaruh signifikan terhadap DDF, KKD, pertumbuhan PDRB per kapita, akan tetapi pertumbuhan PDRB per kapita dan memiliki dampak nyata terhadap turunnya berpengaruh signifikan terhadap tingkat tingkat kemiskinan di Kabupaten Nabire kemiskinan. Hal ini berarti adanya pemekaran tidak memberikan dampak

Tabel 8. Hasil Uji Paired Sample T-Test Kab. Nabire Sebelum dan Setelah Pemekaran

\begin{tabular}{|c|c|c|c|c|c|c|c|c|c|}
\hline \multicolumn{2}{|c|}{ Keterangan } & \multicolumn{8}{|c|}{ Paired Differences } \\
\hline & & \multirow[t]{2}{*}{ Mean } & \multirow[t]{2}{*}{$\begin{array}{l}\text { Std. } \\
\text { Dev }\end{array}$} & \multicolumn{2}{|c|}{$\begin{array}{l}95 \% \text { Confidence Interval } \\
\text { of the Difference }\end{array}$} & \multirow[t]{2}{*}{ value } & \multirow[t]{2}{*}{$\begin{array}{l}\mathrm{D} \\
\mathrm{f}\end{array}$} & \multirow{2}{*}{\multicolumn{2}{|c|}{$\begin{array}{l}\text { Sign. } \\
\text { tailed) }\end{array}$}} \\
\hline & & & & Lower & Upper & & & & \\
\hline Pair 1 & DFA-DFB & -1.00000 & 1.00000 & -3.48414 & 1.48414 & -1.732 & 2 & .225 & \\
\hline Pair 2 & KDA-KDB & -1.33333 & 1.52753 & -5.12792 & 2.46125 & -1.512 & 2 & .270 & \\
\hline Pair 3 & PDA-PDB & -2.83667 & 2.43190 & -8.87784 & 3.20451 & -2.020 & 2 & .180 & \\
\hline Pair 4 & TKA-TKB & 15.01333 & 2.88028 & 7.85831 & 22.16835 & 9.028 & 2 & .012 & \\
\hline
\end{tabular}

Sumber : hasil uji paired sample t-test, SPSS. 


\section{Kabupaten Paniai}

Berikut tabel hasil perhitungan rasio rata-rata per periode Kabupaten Paniai. Pemekaran di Kabupaten Paniai berpengaruh pada naiknya rata-rata nilai derajat desentralisasi fiskal (DDF). Sebelum pemekaran rata-rata nilai DDF Kabupaten Paniai sebesar 2,oo persen naik menjadi 2,67 persen setelah pemekaran. Pemekaran juga berpengaruh pada naiknya nilai kemandirian keuangan daerah (KKD). Sebelum pemekaran rata-rata nilai KKD sebesar 2,oo persen dan naik menjadi 3,oo. Pertumbuhan PDRB per kapita Kabupaten Paniai sebelum pemekaran sebesar 5,20 persen naik menjadi 7,26 persen. Tingkat kemiskinan Kabupaten Paniai turun dari 50,97 persen menjadi 39,42 persen. Berikut hasil uji statistik (Paired Sample TTest) Kabupaten Paniai.

Tabel 9. Hasil Perhitungan Rasio Rata-rata Per Periode Kabupaten Paniai

\begin{tabular}{llll}
\hline Jenis Kinerja & Rumus Rasio & Sebelum & Setelah \\
\hline Desentralisasi Fiskal & PAD/TPD X 100 & 2.00 & 2.67 \\
Kemandirian Keu Daerah & PAD/DPD X 100 & 2.00 & 3.00 \\
Pertumbuhan PDRB Per Kapita & PDRBt - PDRBt-1/PDRBt-1 & 5.20 & 7.26 \\
Tingkat Kemiskinan & $1 \frac{1}{n} \sum_{i-1}^{\alpha}\left[\left(\begin{array}{c}z-y i \\
z\end{array}\right)\right] \alpha$ & 50.97 & 39.42 \\
\hline
\end{tabular}

Hasilnya, pemekaran tidak berpengaruh signifikan terhadap DDF dan pertumbuhan PDRB per kapita, berpengaruh signifikan terhadap tingkat kemiskinan, dan tidak dapat diuji terhadap KKD karena memiliki variansi data nol. Hal ini berarti adanya pemekaran tidak memberikan dampak nyata terhadap kemampuan keuangan daerah, pertumbuhan PDRB per kapita akan tetapi memiliki dampak nyata terhadap turunnya tingkat kemiskinan di Kabupaten Paniai.

Tabel 1o. Hasil Uji Paired Sample T-Test Kab. Paniai Sebelum dan Setelah Pemekaran

\begin{tabular}{|c|c|c|c|c|c|c|c|c|}
\hline \multicolumn{2}{|c|}{ Keterangan } & \multicolumn{7}{|c|}{ Paired Differences } \\
\hline & & \multirow[t]{3}{*}{ Mean } & \multirow[t]{3}{*}{ Std. Dev } & $95 \%$ & Confidence & \multirow{3}{*}{$\begin{array}{l}\mathrm{t} \\
\text { value }\end{array}$} & \multirow{3}{*}{$\begin{array}{l}D \\
f\end{array}$} & \multirow{3}{*}{$\begin{array}{l}\text { Sign. } \\
\text { tailed) }\end{array}$} \\
\hline & & & & Difference & of the & & & \\
\hline & & & & Lower & Upper & & & \\
\hline Pair 1 & DFA-DFB & -.66667 & .57735 & -2.10088 & .76755 & -2.000 & 2 & .184 \\
\hline Pair 2 & KDA-KDB & - & - & - & - & - & 2 & - \\
\hline Pair 3 & PDA-PDB & -2.05333 & 12.39696 & -32.84909 & 28.74242 & -.287 & 2 & .801 \\
\hline Pair 4 & TKA-TKB & 11.55000 & 2.48502 & $5 \cdot 37688$ & 17.72312 & 8.050 & 2 & .015 \\
\hline
\end{tabular}

Sumber : hasil uji paired sample t-test, SPSS. 
Hasil dari uji paired sample t-test untuk diketahui hasil dan ditampilkan dalam tabel 3 masisng-masing variabel per kabupaten, dibawah ini.

Tabel 11. Hasil Rekapitulasi Perhitungan Uji Paired Sample T-Test

\begin{tabular}{|c|c|c|c|c|c|c|}
\hline \multirow{2}{*}{ No } & \multirow{2}{*}{ Daerah Sampel } & \multicolumn{4}{|c|}{ Variabel } & \multirow[t]{2}{*}{$\mathrm{n}$} \\
\hline & & DDF & KKD & PD & TK & \\
\hline 1 & Kab. Jayawijaya & - & - & - & $\sqrt{ }$ & 1 \\
\hline 2 & Kab. Puncak Jaya & $\mathrm{x}$ & - & $\sqrt{ }$ & $\sqrt{ }$ & 2 \\
\hline 3 & Kab. Nabire & - & - & - & $\sqrt{ }$ & 1 \\
\hline \multirow[t]{2}{*}{4} & Kab. Paniai & - & $\mathrm{x}$ & - & $\sqrt{ }$ & 1 \\
\hline & Jumlah yang signifikan & o & o & 1 & 4 & \\
\hline
\end{tabular}

Sumber : Hasil uji paired sample t-test, data diolah.

Keterangan : $(\sqrt{ })$ terdapat perbedaan, (-) tidak terdapat perbedaan, (n) Jumlah

Berdasarkan tabel hasil diatas, dapat diketahui sebagai berikut :

\section{Derajat Desentralisasi Fiskal}

Nilai derajat desentralisasi fiskal di empat kabupaten semuanya mengalami kenaikan setelah mengalami pemekaran kecuali Kab. Puncak Jaya. Namun berdasarkan uji statistik paired sample t-test menunjukan tidak terdapat kabupaten yang menunjukan hasil signifikan. Hal ini tidak sesuai dengan salah satu tujuan pemekaran dalam UU No. 23 tahun 2014 bahwa pemekaran wilayah diharapkan dapat menciptakan percepatan pengelolaan potensi daerah sehingga dapat meningkatkan porsi PAD. Basri (2011:21) menyatakan bahwa Pemekaran daerah menyebabkan biaya belanja daerah yang tinggi, sementara PAD belum bisa meningkat karena baik daerah induk maupun daerah yang mengalami pemekaran, membutuhkan beberapa penyesuaian. Endang Sri Mulatsih (2014) dalam hasil penelitiannya menemukan pemekaran daerah tidak berpengaruh terhadap rasio desentralisasi fiskal.

\section{Kemandirian Keuangan Daerah}

Nilai kemandirian keuangan daerah di empat kabupaten, tiga diantaranya mengalami kenaikan setelah mengalami pemekaran dan satu yaitu Kabupaten Puncak Jaya yang mengalami penurunan. Akan tetapi berdasarkan uji statistik paired sample t-test menunjukan tidak ada kabupaten yang memiliki hasil signifikan. Hal ini tidak sesuai dengan UU No. 23 tahun 2014 bahwa tujuan pemekaran salah satunya adalah pemekaran wilayah diharapkan dapat menciptakan kemandirian daerah dan peningkatan pelayanan kepada masyarakat. Mahmudi (2007:128) menyatakan bahwa Kemandirian Keuangan Daerah menunjukan kemampuan Pemerintah Daerah dalam membiayai sendiri kegiatan pemerintahan, pembangunan dan pelayanan kepada masyarakat yang telah membayar pajak dan retribusi sebagai sumber pendapatan yang diperlukan daerah. Allana Talita Zabrina (2013) dalam hasil penelitian 
Analisis Kinerja Keuangan Pemerintah Daerah Sebelum dan Sesudah Pemekaran menemukan tidak adanya perbedaan rasio kemandirian keuangan daerah dan rasio-rasio lainnya.

\section{Pertumbuhan PDRB Per Kapita}

Nilai pertumbuhan PDRB per kapita di empat kabupaten semuanya mengalami kenaikkan setelah mengalami pemekaran kecuali Kabupaten Puncak Jaya yang mengalami penurunan. Berdasarkan uji statistik paired sample t-test pun menunjukan tidak ada dari empat kabupaten yang menunjukan hasil signifikan kecuali Kabupaten Puncak Jaya yang mengalami penurunan tajam. Hal ini tidak sesuai dengan tujuan pemekaran dalam UU No. 23 tahun 2014 bahwa pemekaran bertujuan mempercepat pelaksanaan pembangunan perekonomian daerah. Menurut Prathama Rahardja dan Mandala Manurung: 2008, perhitungan PDB atau PDRB dapat digunakan untuk menganalisis tingkat kemakmuran suatu daerah, dengan cara membaginya dengan jumlah penduduk, angka tersebut dikenal dengan PDRB per kapita. Makin tinggi pendapatan penduduk, maka singkatnya makin sejahtera pula pendudk tersebut.

\section{Tingkat Kemiskinan}

Nilai tingkat kemiskinan di enam kabupaten semuanya mengalami penurunan setelah mengalami pemekaran. Berdasarkan uji statistik paired sample t-test pun seluruhnya menunjukan hasil signifikan. Menurunnya kemiskinan dikaitkan dengan berkurangnya penduduk miskin ke kabupaten baru pecahan dari daerah induk, sehingga tingkat kemiskinan akan ikut mengalami penurunan. Hal ini sesuai dengan tujuan pemekaran dalam
UU No 23 tahun 2014 pasal 4 ayat 1 bahwa pemekaran bertujuan meningkatkan pelayanan dan mempercepat pembangunan. Implementasi dari adanya pemekaran daerah adalah mengurangi angka kemiskinan, pemekaeran memberikan ruang lingkup pemerintah daerah menjadi lebih kecil sehingga kebijakan-kebijakan akan mudah diaplikasikan.

\section{SIMPULAN}

Berdasarkan hasil penelitian dan pembahasan dapat diperoleh kesimpulan sebagai berikut:

Nilai derajat desentralisasi fiskal tidak terdapat perbedaan yang signifikan untuk seluruh kabupaten periode sebelum dan setelah mengalami pemekaran.

Nilai kemandirian keuangan daerah tidak terdapat perbedaan yang signifikan untuk seluruh kabupaten periode sebelum dan setelah mengalami pemekaran.

Nilai pertumbuhan PDRB per kapita hanya Kabupaten Puncak Jaya yang memiliki perbedaan yang signifikan karena mengalami penurunan yang tajam, sementara itu untuk tiga kabupaten sisanya tidak terdapat perbedaan yang signifikan untuk periode sebelum dan setelah mengalami pemekaran.

Nilai tingkat kemiskinan terdapat perbedaan yang signifikan pada periode sebelum dan setelah mengalami pemekaran untuk seluruh kabupaten.

\section{DAFTAR PUSTAKA}

Abdullah, Rusli. 2013. Faktor-Faktor Yang Mempengaruhi Ketimpangan Pendapatan Di Jawa Tengah. JEJAK Journal of Economics and Policy. Semarang: Semarang State University. diunduh pada laman http://journal.unnes.ac.id/nju/index.php/jejak 
Badan Perencanaan Pembangunan Nasional. 2008. Studi Evaluasi Dampak Pemekaran Daerah 2001-2007. Jakarta: BAPPENAS.

Badan Pusat Statistik Indonesia 2005-2014. Produk Domestik Regional Bruto Kabupaten/Kota di Indonesia 2005-2014. Jakarta: BPS.

Badan Pusat Statistik Kabupaten Nias. 2016. Kabupaten Nias Dalam Angka 2016. Gunungsitoli: BPS.

Badan Pusat Statistik Kabupaten Labuhanbatu. 2015. Kabupaten Nias Dalam Angka 2015. Rantau Prapat: BPS.

Badan Pusat Statistik Kabupaten Kerinci. 2015. Kabupaten Nias Dalam Angka 2015. Sungai Penuh: BPS.

Badan Pusat Statistik Kabupaten Bengkulu Utara. 2015. Kabupaten Bengkulu Utara Dalam Angka 2015. Arga Makmur: BPS.

Badan Pusat Statistik Kabupaten Tanggamus. 2016. Kabupaten Tanggamus Dalam Angka 2016. Kota Agung: BPS.

Badan Pusat Statistik Kabupaten Tulangbawang. 2015. Kabupaten Tulangbawang Dalam Angka 2015. Manggala: BPS.

Direktorat Penataan Daerah, Otonomi Khusus, dan Dewan Pertimbangan Otonomi Daerah. Pembentukan Daerah-daerah Otonom di Indonesia sampai dengan Tahun 2014. Jakarta: Direktorat Jenderal Otonomi Daerah Kementrian Dalam Negeri.

Dirjen Perimbangan Keuangan. 2006-2014. Data Keuangan Daerah Tahun 2006-2014. Dirjen Perimbangan Keuangan. Jakarta: Kementerian Keuangan.

Gunawan, Y. 2013. Kontribusi PBB Pertambangan Migas Bagi Daerah Penghasil Dalam Pelaksanaan Desentralisasi. JEJAK Journal of Economics and Policy. Semarang: Semarang State University. diunduh pada laman http://journal.unnes.ac.id/nju/index.php/jejak

Hidayat, Paidi. dkk, 2007. Analisis Kinerja Keuangan Kabupaten/Kota Pemekaran Di Sumatera Utara (Jurnal Ekonomi Pembangunan). Departemen Ekonomi Pembangunan: Jakarta. Universitas Sumatera Utara.

Purba Riani, I.A. dkk. 2012. Analisis Dampak Pemekaran Wilayah Terhadap Pendapatan Per Kapita, Kemiskinan, dan Ketimpangan Antar Wilayah di Provinsi Papua. Jurnal Bumi Lestari. Jayapura: Fakultas Ekonomi Universitas Cendrawasih, Jayapura.

Putra, W. 2012. Efisiensi Dan Efektivitas Pelayanan Rumah Sakit Setelah Pemekaran Wilayah. JEJAK Journal of Economics and Policy. Semarang: Semarang State University. diunduh pada laman http://journal.unnes.ac.id/nju/index.php/jejak

Sri Multasih, Endang. 2014. Analisis Kemampuan Keuangan Daerah Kabupaten/Kota Di Provinsi Sumatera Selatan Sebelum dan Setelah Pemekaran Daerah. Jurnal Ekonomi dan Informasi Akuntansi (Jenius). Palembang: STIE Mulia Darma Pratama.

Suseno, Deky Aji (2013). Efektivitas dan Kemandirian Keuangan Daerah Provinsi Jawa Tengah Pasca Diterapkannya Desentralisasi Fiskal. Economics Development Analysis Journal, 2(2). doi:10.15294/edaj.v2i2.1710

Talita Zabrina, Allana. 2013. Analisis Kinerja Keuangan Pemerintah Daerah Sebelum dan Sesudah Pemekaran. Skripsi. Surakarta: Fakultas Ekonomi UNS.

Tiebout, C.M. 1956. A Pure Theory of Local Expenditures. The Journal of Political Economy. 64(5): pp. 416424 .

Undang-Undang Nomor 23 Tahun 2014 